\title{
A Tribute to Racovitza
}

\author{
M. Martínez-Gil, A. I. Camacho \& A. G. Valdecasas
}

"La chasse aux Cavernicoles présents des dificultes que
nos confrères qui chassent le Lucicole ignorent. Et
certes, une observation faite dans les grottes devrait,
comme les années de champagne, compter double".

Émile G. Racovitza, 1907, Biospeologica I, Banyuls-sur-Mer (France)

Only the passage of time will tell if the contribution made by a researcher will be considered a 'landmark' in the development of his or her discipline. This should not be forgotten in an age in which specialists involved in a particular area of research often claim for themselves the recognition of originality, a 'paradigm shift', or a landmark contribution among other devaluated sociological terms. While the perception of contribution to science is a complex subject, andrelated to financial support, only an appropriate perspective can determine who deserves the merit for that contribution. It is easy for us, for instance, to point out to the Linnaeus Systema Naturae as a milestone in the development of the natural sciences, and as we argue below, a similar case can be made for Racovitza's contribution to Biospeleology.

The development of scientific knowledge during the seventeenth and eighteenth centuries separated what was 'natural philosophy' from all other thought disciplines and transformed it into what was called Natural History. As such, it included the sciences of the earth and life, while other phenomena were included in what was called 'recreational physics' encompassing physics and chemistry, among other disciplines. Finally, as knowledge became more analytic and specialized, labels appeared for the basic disciplines as we know them today -geology, anthropology, biologyand the concept of Natural History remained a general term that included a comprehensive (not holistic!) grouping of all of those specialties. A good historical exercise on this concept is Hutchinson's (1977) essay on the influence of the New World on Natural History, in which he selected three earlier researchers that dealt with the development of animals, the study of organic variation and the numerical progression of populations. A much deeper discussion still current is to be found in the first chapter of Crowson's (1969) seminal work Classification and Biology.

By the end of the eighteenth century, the specific programs of the different disciplines in the natural sciences had been established and were 'pursued at major scientific institutions and prosecuted with narrowing focus on detailed areas' (Sloan, 2006). This trend deepened in the following century.

This is the frame of reference that should be used to understand and evaluate the role played by Emil Racovitza, whose $100^{\text {th }}$ anniversary we celebrated this year, in the foundation of modern Biospeleology.

\section{Father of the Modern Biospeleology}

Emil Gustave Racovitza (1868-1947) was a naturalist in the broad sense of the word. Born in Romania, he studied law in Paris but devoted his effort and attention to the study of natural sciences, especially zoology, producing a doctoral thesis on the Annelid nervous system in 1896. He participated in the Belgian International Expedition to the South Pole at the end of the century. He worked at the research station 'Laboratoire Arago' at Banyuls-surMer (France) and co-directed the publication Archives de Zoologie Expérimentale and Générale.

In 1904, Racovitza visited the cave of Drac on the Isle of Majorca (Spain) and described the sub- 
terranean crustacean, Thyphlocirolana moraguesi (Racovitza, 1905), which impressed him with unusual characteristics such as blindness and depigmentation. The discovery of the subterranean isopod awakened his interest for the subterranean milieu and its associated fauna and he decided to invest his time and efforts to the study of the subterranean environment. Three years later he published Essai sur les problèmes biospéologiques, a balance of previous research, methodological and conceptual criticism and a detailed program for the future of this discipline, which is still current today. Returning to Romania, he founded the Institute of Speleologie in Cluj, the first of this specialty in the world. He continued working on subterranean life until his death in 1947.

When Racovitza started to study the contemporary biogeographical work on the subterranean environment he did not find any information related to the subterranean fauna. Rather, the primary literature would mention the insignificance of the subterranean habitat and the lack of importance of its fauna (Ratzel, 1902).

The specialized works at the end of the nineteenth century (Packard, 1889; Hamann, 1896; Viré, 1899; Chilton, 1894; Joseph, 1882; etc.) did not address any of Racovitza's concerns. The studies he carried out revealed an unclear and incomprehensible network of concepts and generalizations unfounded and contradictory scientific theories and observational and interpretational errors.

He was confounded in the reading of texts such as: "Live in full darkness conditions necessarily produces blindness" (Packard, 1889); "Blindness is not necessarily produced by a full darkness live" (Semper, 1880); "Lack of light is not the efficient reason of blindness, which may be produced by unknown factors" (Hamann, 1896); "Caves are not completely dark and it explains the existence of eyed cave dwellers" (Hamann, 1896); "Deep caves are characterised by full darkness" (Verhoeff, 1898); "Blinded cave dwellers have lost theirs eyes after the cave immigration" (Packard, 1889; Viré, 1899); "Cave dwellers special features have been acquired by slow evolution processes" (Darwin, 1859); "By rapid evolution processes" (Packard,
1889); "By sharp changes" (Eigenmann, 1898); "Organs development underneath a darkness environment undergo through a lot of changes occurring in the earliest generation" (Viré, 1899).

Racovitza was first to establish and define the true conditions of the subterranean environment and their influences on cave dwellers, making an important and original contribution within the scientific context of the time. Assuming some observations that basically characterize the subterranean milieu such as permanent darkness, steady temperature, high humidity and low food supply in some parts of the cave environment, he described the influences of the subterranean milieu on the forms of cave dwellers as follows:
'Emile G. Racovitza, Photo courtesy of S. Iepure.

1.- Lack of light conditions and influences the pigmentation, the optical system, the development of non-visual sensory organs and the cave dwellers' behaviour.

2.- Relative unchanging and low temperatures might reduce the adaptation capacity to overcome environmental changes, produce lack of reproductive and lethargy periods and a decrease of functional activity.

3.- Subterranean high humidity might provide an advantage over the epigean milieu, because it reduces corporal evaporation.

4.- Absence of plants and external food resources in caves compel cave dwellers to follow a carnivorous and saprophagous feeding regime. The idea of a continuous scarcity of food in the subterranean environment cannot be accepted.

5.- Despite some authors' opinions, the fight for survival is incessant in the subterranean environment and therefore natural selection acts on individuals and species.

After he reviewed all subterranean fauna known at that time, Racovitza reasserted his first appreciation about subterranean fauna: "the only thing these living beings have in common is the habitat; cave dwellers are a heterogeneous mix of different forms, origins, inheritance aptitudes, organization 
ranges and immigration periods to the caves" (Racovitza, 1907).

His first supposition to explain the disorganization of Biospeleology at that time was the situation of the discipline as an incipient science. He pointed out the obstacles and difficulties to avoid and the future direction that the discipline should follow.

Racovitza believed it was the right moment for building general theories, proceeding with analysis and tackling the shortage of biological and taxonomic works on subterranean fauna; he considered that point as an adequate time to begin shedding light on subterranean natural history. Erroneus interpretations and generalizations at the end of the nineteenth century may have given way to facts and observations. He suggested an intensive global research agenda, studying the largest number of caves possible in the greatest number of varied regions to fill the absence of subterranean faunal and floral knowledge, and encouraged rigorous investigation and experimentation in the subterranean environment.

After the publication of his work, Racovitza founded the energetic association "Biospeologica", originally established at the Laboratoire Arago (France), and once in Romania, he created the Institut de Spéologie, at Cluj. At that time a new and promising period of biospeleological research began. Many speleological expeditions were carried out, especially in Europe, Africa and North America. Large amounts of material were collected and identified, concluding with the publication of eighty-one monographic papers covering all zoological groups (Camacho, 1992) in the series Biospéologica which was placed into the Archives de Zoologie Expérimentale et Générale.

Throughout the second half of the twentieth century, taxonomic studies predominated, and paved the way for ecological and physiological research. Physiological research on biological cycles and reproduction of cave invertebrates began after nearly half a century of the origin of the modern Biospeleology (Deleurance-Glaçon, 1963). Studies on morphological and physiological adaptations declined after the 60's and 70's (Bellés, 1992), perhaps, as pointed out by Culver (1982), because they no longer appeared modern. Some notable exceptions are studies by Holsinger \& Culver (1970) and Wilkens (1987) on morphological variation in Gammarus minus, and studies on morphology and genetics of regressive characters in cave fishes, respectively. Indeed problems of biology, cave colonization, speciation and evolution of aquatic organisms prompted many and significant studies
(Barr et al., 1960; Delamare-Deboutteville, 1960; Ginet, 1960; Vandel, 1964; Holsinger, 1967; Ginet \& Decou, 1977; Culver, 1982; Rouch, 1986; Culver et al., 1995; Holsinger, 2000). Some of these works made possible the appearance of two key monographs that integrated and summarized all the information compiled at that time: Biospéologie (Vandel, 1964), with an orthogenetic perspective, and Cave ecology and the evolution of troglobites (Barr, 1968), within the frame of Neodarwinism.

Modern Biospeleology reached the starting point discussed by Racovitza, after half a century of expeditions and studies. From here, general theories, specific monographs and biology, colonization, speciation and evolution studies should have allowed the resolution of the subterranean faunal history. From a morphological and physiological point of view, only a few studies were conducted, concluding with many unanswered questions.

As the responses of subterranean animals to similar demands vary greatly, it is difficult to make generalizations in this regard. At most a general trend could be discerned for some characterisitics. The characters called "predictive adaptations" (Vandel, 1964; Culver, 1982) or just adaptations to the environment (Barr, 1968; Barr \& Holsinger, 1985 ) are often convergent characters but they must be correctly evaluated in order to determine whether or not they are adaptive. In the current scientific context, it is not clear what percentage of the apparent convergence is due to inheritance from ancestors (phylogeny) and what to true convergence (adaptation) (Camacho et al., 1992). We need an objective way of deciding whether a character present in an organism is primitive or is derived.

A substantial number of studies on the behavioural, morphological, physiological and metabolic effects of starvation in many taxa have been made (Poulson, 1964; Mathieu \& Gilbert, 1980; Hervant et al., 1996, 1997, Langecker, 2000; Hervant \& Renault, 2002). Nevertheless many questions remain unanswered, and there is still much to learn from future research.

Returning to Racovitza' essay, everything he then stated remains valid today, showing the short advancement achieved in the knowledge of the subterranean biology, and also demonstrates how visionary and up to date he was. The Essai is still the most relevant document to recognize Biospeleology as a modern science. Racovitza is one of few naturalists to make such an important contribution and so ahead of his time, and that is the reason for him to be considered the father of Modern Biospeleology. 


\section{Selected References}

BarR, T. C. JR. \& Holsinger, J. R., 1985. Speciation in cave fauna. Annual Review on Ecology \& Systematic, 16: 313-337.

Bellés, X., 1992. From dragons to allozymes. In: A.I. Camacho (ed.). The Natural History of Biospeleology. Monography 7, Museo Nacional de Ciencias Naturales, C.S.I.C. Madrid: 3-24.

Camacho, A. I., Bello, E., Becerra, J. M. \& Vaticón, I., 1992. A natural history of the subterranean environment and its associated fauna. In: A.I. Camacho (ed.). The Natural History of Biospeleology. Monography 7, Museo Nacional de Ciencias Naturales, C.S.I.C. Madrid: 171-197.

Culver, D. C., 1982. Cave life. Evolution and ecology. Harvard University Press. Harvard. 189 pp.

Delamare-Deboutteville, C., 1960. Biologie des eaux souterraines littorals et continentals. Hermann. Paris. 740 pp.

Eigenmann, C. H., 1898. The origin of cave Faunas. Proceedings of the Indiana Academy of Science, 1897: 229-230.

Ginet, R. \& DeCou, V., 1977. Initiation à la biologie et à l'écologie souterraines. Jean-Pierre Delarge. Paris. $345 \mathrm{pp}$.

Hamman, O., 1896. Europäische Höhlenfauna. Eine Darstellung der in den Hölen Europas lebeden Tierwelt mit besonderer Berücksichtigung der Höhlenfauna Krains. Cortenoble. Jena. 296 pp.

Hervant, F. T. \& Renault, D., 2002. Long-term fasting and realimentation in hypogean and epigean isopods: a proposed adaptive strategy for groundwater organisms. The journal of experimental biology, 205(14): 2079-2087.

Hutchinson, G. E., 1977. The influence of the new World on the study of Natural History. In: Clyde E. Goulden (ed.). Changing scenes in Natural Sciences, 17761976. Academy of Natural Sciences of Philadelphia. Pennsylvania: 13-34.
LANGECKER, T. G., 2000. The effects of continuous darkness on cave ecology and cavernicolous evolution. In: H. Wilkens, D. C. Culver \& W. F. Humphreys (eds). Ecosystems of the World, 30: Subterranean Ecosystems. Eselvier. Amsterdam, Oxford, etc.: 135157.

PACKARD, A. S., 1889. The cave fauna of North America, with remarks on the Anatomy of the brain and origin of the blind species. Memorial National Academy of Science. Washington. $156 \mathrm{pp}$.

RACOVITZA, E. G., 1907. Essai sur les problèmes biospéologiques. Bioespeologica 1. Archives de Zoologie Expérimentale and Générale, 4: 371-488.

VAndel, A., 1964. Biospéologie. La biologie des animaux cavernicoles. Gauthier Villars. Paris. 619 pp.

VIRÉ, A., 1899. Essai sur la fauna obscuricole de France. Etude particulière de quelques formes zoologiques. Baillère et fils. Paris. $157 \mathrm{pp}$. 